\title{
The generation and use of cumulative probability distributions in flood risk assessment for the Mfolozi flood-plain
}

\author{
LA du Plessis \\ PO Box 339, Department of Agricultural Economics, University of the Free State, Bloemfontein, 9300
}

\begin{abstract}
The traditional method of presenting flood damage is to calculate the mean annual flood damage. This approach does not explicitly point out the risk of floods and communities do not have an indication of what the risk implications of various floods are. A clearer picture of the uncertainty of flood damages as well as the damage implications can be created by constructing and using cumulative probability distribution curves. The inclusion of flood damage on a stochastic basis is most definitely an extension of previous flood research, which only used deterministic analysis. With this approach, flood-plain dwellers can comprehend better the nature, scope and potential effects of the risk invalued. The main aim of this paper is to explain better the potential risk of floods to flood-plain dwellers by constructing and using cumulative probability distribution curves.
\end{abstract}

\section{Introduction}

Traditionally, potential flood damage was determined by calculating the mean annual flood damage (MAD). Important information, such as the average potential flood damage per annum, was obtained by means of this method. Notwithstanding the fact that this traditional method also provides limited risk information regarding individual potential floods, such as the probability of occurrence, it does not provide any risk information to flood-plain dwellers that will enable them to comprehend fully the financial implications of the risk involved.

To accommodate the above-mentioned limits, an adapted approach was developed to explain better the risk of floods to the community by constructing and using cumulative probability distribution (CPD) curves. A study of international literature revealed that there is very little, if any, information available on this adapted approach towards explaining the risk of potential flood damages. One reason may be the absence of agricultural economists in flood damage research. The international trend is to move away from engineer solutions and to move towards risk assessment, prevention and mitigation strategies. By using CPD the risk of flooding can be explained better. It is not the purpose of this paper to discuss the methodology of flood damage assessment, nor the detail of the flood damage simulation model (FLODSIM) exhaustively, mainly because these aspects have already been discussed. For more details regarding the last-mentioned, see Du Plessis (1998), du Plessis and Viljoen (1995; 1996 and 1997) and Berning et al. (2000).

The main aim of this paper is to explain better the potential risk of floods to flood-plain dwellers. The procedures and data collection will be discussed first. Thereafter, the total mean annual flood damage will be calculated by using an appropriate simulation model. Lastly, a cumulative probability distribution curve will be constructed and discussed.

* To whom all correspondence should be addressed.

疅(051) 401-2721; fax (051) 448-0692; e-mail: anton@landbou.uovs.ac.za Received 10 December 1998; accepted in revised form 4 September 2000.

\section{Procedures}

After developing an appropriate flood damage simulation model (FLODSIM) for the Orange River at Upington, it was decided to further develop FLODSIM for wider application in other floodprone areas. The Mfolozi flood-plain (8 $500 \mathrm{ha}$ ) was used as the study area and various types of data had to be collected for this area.

\section{Collection of data}

Types of data normally required for flood damage simulation purposes are topographical, hydrological and economic data. Such data must first be converted to the correct format for integration with FLODSIM. Before a typical flood damage simulation system can be discussed, it is first necessary to discuss the collection of the different types of data.

\section{Topographical data}

Land use, roads, tramways, levees, drainage systems and rivers in the Mfolozi area were digitised from 1:10000 orthophotos. Unfortunately, the most recently available orthophotos were created using 1979 photography. The digitised data were updated with the aid of information derived from 1996 aerial hotographs and Bosch \& Associates in Durban made this digital information available. After this information had been obtained, it was possible to create a digital terrain model (DTM) for the Mfolozi flood-plain.

Two methods, namely a digital photogrammetry and an analogue stereoplotter, were mainly used to create a DTM. For this purpose the Helava Digital Photogrammetic Stereoplotter installed on a Sun Ultra computer was used to obtain a DTM for the Mfolozi flood-plain from controlled aerial photography at a scale of 1:30 000 (Schutte, 1997). A photogrammetric scanner was used to convert the analogue diapositives into a digital image format used by the Helava system, namely VITEC. Caution must be taken when ground control points are entered to ensure that the different images will connect at the same level. As sugar-cane in the Mfolozi floodplain is cut at different times of the year and is thus not always of the same height, compensations had to be made for the height of sugar-cane in each cultivated field. The results from this method 
were unreliable due to the dense vegetation and a second DTM was, therefore, created with the aid of an analogue stereoplotter. With this method points within cultivated fields could be ignored.

\section{Hydrological and hydraulic data}

The Hydraulic Studies Subdirectorate of the Department of Water Affairs and Forestry provided all the hydrological and hydraulic data for the Mfolozi flood-plain. Hydraulic data were created by means of a dynamic hydraulic simulation model, Mike 11 (Cai and Myburgh, 1998). The cross-sections and river network required by Mike 11 to describe the river morphology were defined by means of FLODSIM itself (something that was not possible in the past).

In contrast to vineyards, the duration of inundation is the most important variable that determines flood damage in the case of sugar-cane. In addition to the depth of the inundation and the velocity of floodwaters, the duration of the inundation in the form of flood hydrographs was obtained from MIKE 11. The duration of inundation is explicitly taken into account with regard to sugarcane loss functions.

\section{Infrastructure}

In addition to damage to sugar-cane, damage to infrastructure in the Mfolozi flood-plain does occur. Appropriate loss functions were therefore constructed for infrastructure such as levees, drainage systems, roads, bridges and tramways in the Mfolozi flood-plain. A loss function defines the relationship between flood damage and certain characteristics of a flood. Depth of inundation of the infrastructure is calculated by means of FLODSIM. With the inundated level known to infrastructure, the total damage to infrastructure is determined by multiplying the rand value of damage per $\mathrm{km}$ by the total length of inundated infrastructure.

\section{Economic database}

Only sugar-cane is cultivated on the Mfolozi flood-plain and an enterprise budget was drawn up for sugar-cane. Regional and national multipliers were also calculated for this region in order to assess the secondary effects of floods. However, the calculation of the secondary effects of floods on the Mfolozi flood-plain falls outside the scope of this paper. Table 1 shows the economic data for the Mfolozi flood-plain that were used for simulation purposes.

\begin{tabular}{|l|c|}
\hline \multicolumn{2}{|c|}{ TABLE 1 } \\
Economic data for the Mfolozi flood-plain (1995 \\
values) for the calculation of the total direct flood \\
damages
\end{tabular}

\section{Assimilation of data}

Flood damage simulation model (FLODSIM)

After all the data (topographical, hydraulic, land-use, loss functions and economic data) had been collected, it was possible to integrate all the data with FLODSIM (Fig. 1) to first calculate the monthly flood damage. Thereafter, it was possible to determine the MAD. The following formulas were used to calculate harvest and crop damage (See Berning et al. (2000) for a detailed discussion):

\section{Harvest damage}

According to Viljoen et al. (1981) damage to the harvest comprises the loss when crops are partially or completely damaged during a flood. Damage to the harvest (DH) is calculated as the decrease in income due to destroyed sugar-cane (D), minus the resultant decrease in cost (B) (harvesting cost saved as a result of the smaller harvest), plus the decrease in income due to lower sucrose content (P):

$$
\mathrm{DH}=\mathrm{D}-\mathrm{B}+\mathrm{P}
$$

The decrease in income due to destroyed sugar-cane (D) was calculated as follows:

$$
\begin{aligned}
& D=\sum_{L=0.1}^{N} D_{L} \\
& D_{L}=A_{L} * A * H_{L} / H * C * S_{h} * G I_{S}
\end{aligned}
$$

where:

$\mathrm{D}(\mathrm{R})=$ Decrease in income (destroyed cane)

$\mathrm{N}(\mathrm{m})=$ Depth of inundation

$\mathrm{D}_{\mathrm{L}}(\mathrm{R})=$ Decrease in income for cane with height $\mathrm{L}$

$A_{L}(\%)=$ Percentage area with destroyed sugar-cane of height $\mathrm{L}$

$\mathrm{A}(\mathrm{ha})=$ Total area under cane

$\mathrm{H}_{\mathrm{L}}(\mathrm{m})=$ Height of destroyed cane $(0.1 \mathrm{~m}-2.4 \mathrm{~m})$

$\mathrm{H}(\mathrm{m})=$ Average height of mature cane $(2.1 \mathrm{~m})$

$\mathrm{C}(\mathrm{t} / \mathrm{ha})=$ Tons of cane per hectare

$\mathrm{S}_{\mathrm{h}}(\%)=$ Percentage sucrose

$\mathrm{GI}_{\mathrm{S}}(\mathrm{R} / \mathrm{t})=$ Gross income per ton sucrose

The decrease in harvesting cost (B) is a function of, firstly, the amount of ton sugar-cane destroyed and, secondly, the harvesting and transport costs per ton:

$$
B=\frac{D}{G I_{C}} * M_{C}
$$

where:

$$
\begin{array}{ll}
\mathrm{B}(\mathrm{R})= & \text { Decrease in harvesting cost } \\
\mathrm{D}(\mathrm{R})= & \text { Decrease in income (destroyed cane) } \\
\mathrm{GI}_{\mathrm{C}}(\mathrm{R} / \mathrm{t})= & \text { Gross income per ton cane } \\
\mathrm{M}_{\mathrm{C}}(\mathrm{R} / \mathrm{t})= & \text { Harvesting cost per ton cane-Includes transport } \\
& \text { cost }
\end{array}
$$

The third component of Eq. (1) refers to partially damaged sugarcane $(\mathrm{P})$, which is cane that can still be harvested after the flood, but the quality (sucrose content) of which has deteriorated as a result of an oxygen shortage in the root zone during floods, can be calculated as follows:

$$
P=A_{P} *\left(1-A_{D}\right) * A * C *\left(S_{H}-S_{L}\right) * G I_{S}
$$

where:

$$
A_{D}=\sum_{L=0.1}^{N} A_{L}
$$


$\mathrm{P}(\mathrm{R}) \quad=$ Decrease in income (partially damaged sugar cane)

$\mathrm{A}_{\mathrm{P}}(\%)=$ Percentage of area not destroyed, where cane has been partially damaged

$\mathrm{A}_{\mathrm{D}}(\%)=$ Percentage area with destroyed cane

$\mathrm{A}(\mathrm{ha})=$ Total area cane

$\mathrm{C}(\mathrm{t} / \mathrm{ha})=$ Tons sugar-cane per hectare

$\mathrm{S}_{\mathrm{H}}(\%)=$ Normal (higher) sucrose content

$\mathrm{S}_{\mathrm{L}}(\%)=$ Lower sucrose content after flood

$\mathrm{GI}_{\mathrm{S}}(\mathrm{R} / \mathrm{t})=$ Gross income per ton of sucrose

$\mathrm{N}(\mathrm{m}) \quad=$ Depth of inundation

$\mathrm{A}_{\mathrm{L}}(\%)=$ Percentage area with destroyed cane of height $\mathrm{L}$

The area with partially damaged cane is expressed as a percentage of the area not destroyed by the flood. This percentage is assumed to increase with an increase in depth of inundation, while the area under undamaged sugar-cane, is expected to decrease. The relationship between the total area under cane and areas with destroyed, damaged and undamaged cane respectively after flooding, can be depicted as follows:

$$
\text { Area }=A_{D}+A_{P} *\left(1-A_{D}\right)+A_{N} *\left(1-A_{D}\right)
$$

where:

$$
\begin{aligned}
& A_{P}+A_{N}=1 \\
& \text { Area (ha) }=\text { Total area } \\
& \mathrm{A}_{\mathrm{D}}(\%)=\text { Percentage area under destroyed cane } \\
& \mathrm{A}_{\mathrm{P}}(\%)=\text { Percentage area under partially damaged cane } \\
& \mathrm{A}_{\mathrm{N}}(\%)=\text { Percentage area under undamaged cane }
\end{aligned}
$$

\section{Crop damage}

In the case of perennial crops such as sugar-cane, damage to crops can occur in addition to damage to the harvest. The effect of damage to the crop is usually spread over a number of years and can be reflected by lower than normal yields for a few years following the flood (Viljoen 1979).

After a flood the farmer has two options and his decision depends largely on the extent of the damage. It was assumed that if less than $30 \%$ of the sugar-cane has been destroyed, farmers will not re-establish production and production will continue with less than optimal yields during the following two years, but that farmers will re-establish sugar-cane if more than $30 \%$ of the sugar-cane has been destroyed. If a farmer decides to continue production with damaged crops, the damage to the crop is calculated as the discounted value of the decrease in income minus the saving in harvesting costs for the period during which a lower yield is obtained (Viljoen 1979). (IC):

Damage to the crop if the farmer does not re-establish cane

$$
\mathrm{IC}=\mathrm{NPV}_{1}-\mathrm{NPV}_{2}
$$

Damage to the crop if the farmer does re-establish cane (IE):

$$
\mathrm{IE}=\mathrm{NPV}_{1}-\mathrm{NPV}_{3}
$$

Net present value of the gross margin $=\mathrm{NPV}_{\mathrm{IJK}}$

where:

$$
\begin{aligned}
& \mathrm{I}=1 \ldots 3 \quad 1=\text { normal production pattern } \\
& 2=\text { production with damaged cane } \\
& 3=\text { re-establish cane }
\end{aligned}
$$

$$
\begin{aligned}
& \mathrm{J}=1 \ldots 10 \quad \text { year of cane establishment } \\
& \mathrm{K}=1 \ldots 10 \quad \text { year } \\
& \mathrm{NPV}_{1.1}=\mathrm{PV}_{1.1 .1}+\mathrm{PV}_{1.1 .2}+\ldots .+\mathrm{PV}_{1.1 .10} \\
& \mathrm{NPV}_{1.2}=\mathrm{PV}_{1.2 .1}+\mathrm{PV}_{1.2 .2}+\ldots .+\mathrm{PV}_{1.2 .10} \\
& \mathrm{NPV}_{1.10}=\mathrm{PV}_{1.10 .1}+\mathrm{PV}_{1.10 .2}+\ldots .+\mathrm{PV}_{1.10 .10}
\end{aligned}
$$

Hence:

$$
\mathrm{NPV}_{1}=\left(0.1 * \mathrm{NPV}_{1.1}\right)+\left(0.1 * \mathrm{NPV}_{1.2}\right)+\ldots .+\left(0.1 * \mathrm{NPV}_{1.10}\right)
$$

Similarly:

$$
\begin{aligned}
& \mathrm{NPV}_{2}=\left(0.1 * \mathrm{NPV}_{2.1}\right)+\left(0.1 * \mathrm{NPV}_{2.2}\right)+\ldots .+\left(0.1 * \mathrm{NPV}_{2.10}\right) \\
& \mathrm{NPV}_{3}=\left(0.1 * \mathrm{NPV}_{3.1}\right)+\left(0.1 * \mathrm{NPV}_{3.2}\right)+\ldots .+\left(0.1 * \mathrm{NPV}_{3.10}\right)
\end{aligned}
$$

In the case of re-establishment $(I=3)$, it was assumed that the whole area was re-established in the first year after the flood. The formula for $\mathrm{NPV}_{3}$ is thus reduced to the following:

$$
\mathrm{NPV}_{3}=\mathrm{NPV}_{3.1}=\mathrm{PV}_{3.1 .1}+\mathrm{PV}_{3.1 .2}+\ldots .+\mathrm{PV}_{3.1 .10}
$$

With FLODSIM it is also possible to formulate appropriate flood damage prevention and mitigation strategies, which can lead to sustainable development practices. However, the discussion of the latter-mentioned falls outside the scope of this paper (for detailed discussion refer to Du Plessis 2000).

\section{Flood risk assessment}

Farming in flood-plains is a financially risky occupation, mainly because of periodic flooding. Understanding risk is a key element in helping producers make better decisions in risky situations, and also provides useful information to policymakers in assessing the effectiveness of different types of risk-protection tools. Risk is uncertainty that affects an individual's welfare and is often associated with adversity and loss (Bodie and Merton 1998). Risk is uncertainty that "matters" and may involve the probability of losing money, possible harm to human health, repercussions that affect resources (e.g. irrigation) and other types of events that affect a person's welfare. Uncertainty (a situation in which a person does not know for sure what will happen) is necessary for risk to occur, but uncertainty need not lead to a risky situation (Harwood et al. 1999).

There are many types of risks that are very important to producers, but for the purpose of this paper only flood risk will be dealt with. Flood damage is traditionally expressed in terms of the mean annual flood damage, especially when flood-control measures are evaluated. When presenting information using this approach, the risks of floods cannot be comprehended clearly. An adapted approach was developed to point out the risks of potential flood damage to communities. This approach entails the constructions of cumulative probability distribution curves (CPDC). The main advantage of using CPDC is mainly to move from a single value (normally the average value $=$ MAD) to a stochastic approach. When presenting flood damage in this way, it is possible to also indicate the risk of the distribution of flood damage beside the probability of occurrence. These advantages of the CPD have not yet been applied to flood damage, and it was decided to adopt this approach in flood damage risk assessment.

Flood damage results obtained by using CPDC will be discussed next. 


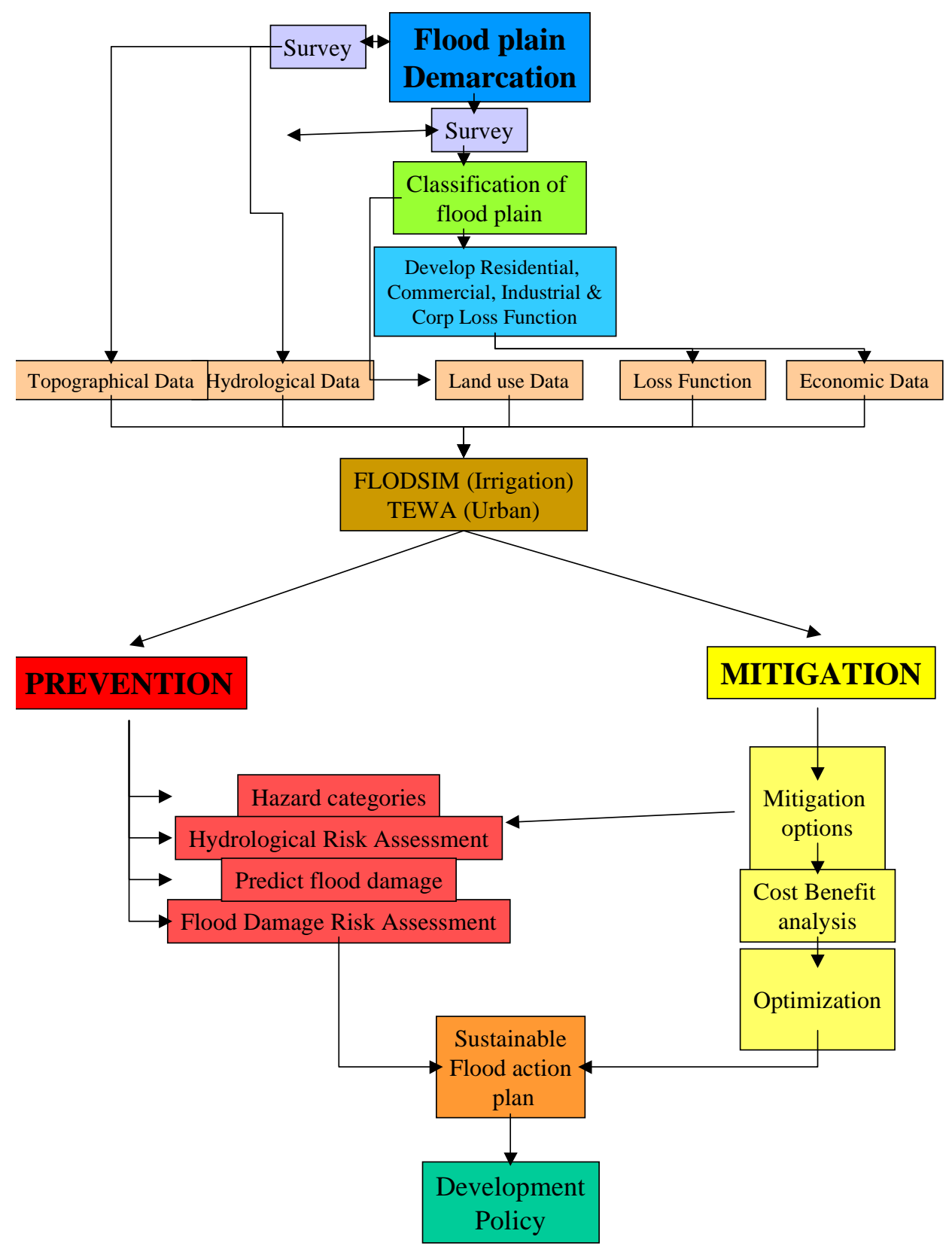

Figure 1

A typical flood damage simulation

\section{Empirical results}

\section{Total mean annual flood damage}

Floods in the Mfolozi flood-plain could occur every month of the year. Consequently the flood damage (harvest and crop damage without damage to infrastructure) was calculated for the year (Fig. 2) by using FLODSIM.

A clear distinction is made between summer and winter flood damage. From November to April damage above the average occurs and it increases from month to month during that period. The mean annual damage for the summer months varies from R2.39 m. (November) to R2.8 m. (April). Flood damage from May to October differs little and the total mean annual flood damage for these months varies between R1.56 to R1.58 m.
With the monthly flood damages known, it is possible to determine the total mean annual flood damage for the Mfolozi flood-plain. The total mean annual flood damage for an April flood (this is the flood with the highest risk for the Mfolozi flood-plain) amounts to R3.27 m. (Fig. 2). Flood damage decreases to R2 m. when floods occur during the winter months. The average potential flood damage for the Mfolozi flood-plain is R2.54 m. when damage to infrastructure is also added to the potential damage to cane. The variation between the total mean annual flood damage, when damage to infrastructure is included, and the mean annual flood damage when damage to infrastructure is excluded, is shown graphically in Fig. 2.

The composition of damage to infrastructure is shown graphically in Fig. 3. 




Figure 2

Total mean annual damage for floods in various seasons, with and without damage to infrastructure, 1995

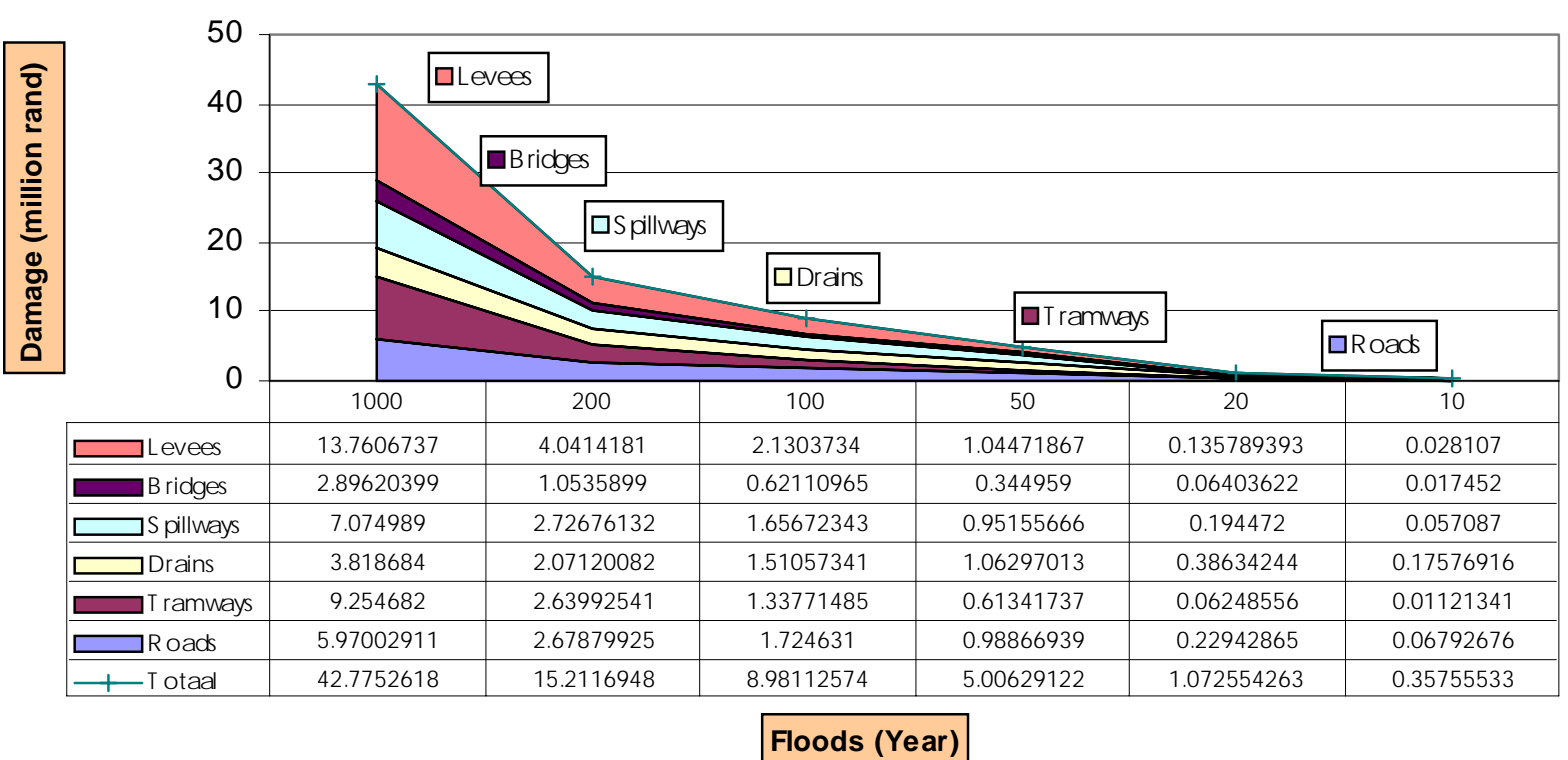

Figure 3

Composition of infrastructure damage

The largest mean annual damage, namely $29 \%$, is caused to levees, followed by damage to tramways (19\%). Damage to the spillway comprises $17.25 \%$ of the total damage to infrastructure, while $16 \%$ of the total damage is caused to roads. Bridges represent the smallest component $(6.8 \%)$ of damage to infrastructure.

\section{Cumulative probability distribution}

From this information it was possible to construct appropriate CPDC. To illustrate the adoption of CPD to flood damage, the two outer boundaries of flood damage were used as a starting point. Flood damage was plotted against the cumulative flood probabilities (Fig. 4). Damage to infrastructure was included.

The April and June flood lines in Fig. 4 show the outer boundaries of floods in the Mfolozi flood-plain, followed by a January and October flood respectively. There is a $10 \%$ chance that damage, depending on the time of the year in which the flood occurs, can vary between R8.19 and R13.74 m. in any year. There is a 5\% chance that flood damage amounting to between R9.69 and $\mathrm{R} 17.71 \mathrm{~m}$. can occur in any year. It is evident that floods that occur during April hold a higher risk of damage for the community, while a June flood causes the least damage. While the mentioned curves are initially (with a smaller flood) very high, it can be assumed that a specific damage in a specific year cannot be exceeded (Van Zyl, 1998). This is true because the largest contribution to the total mean annual flood damage can to a large extent be ascribed to smaller floods. Damage can vary between R57.5 (June) and R71 m. (April) in any year, although the chance of occurrence is only $1 \%$.

Although it can be assumed that the damage figures in Fig. 4 will not be exceeded, the extent of certainty ( $\%$ assurance) is not known. Therefore, it is necessary to discuss additional information, namely the cumulative flood damage probability distribution (Fig.5). Firstly, it was necessary to make the following assumptions:

- As a starting point it was decided to follow an approach of damage occurring, against no damage occurring. The assumption was that in the absence of a flood, no damage will occur. Because of a lack of historical flood records, it was not possible to determine exactly the number of times that a flood of a specific size occurred over a long period of time. 


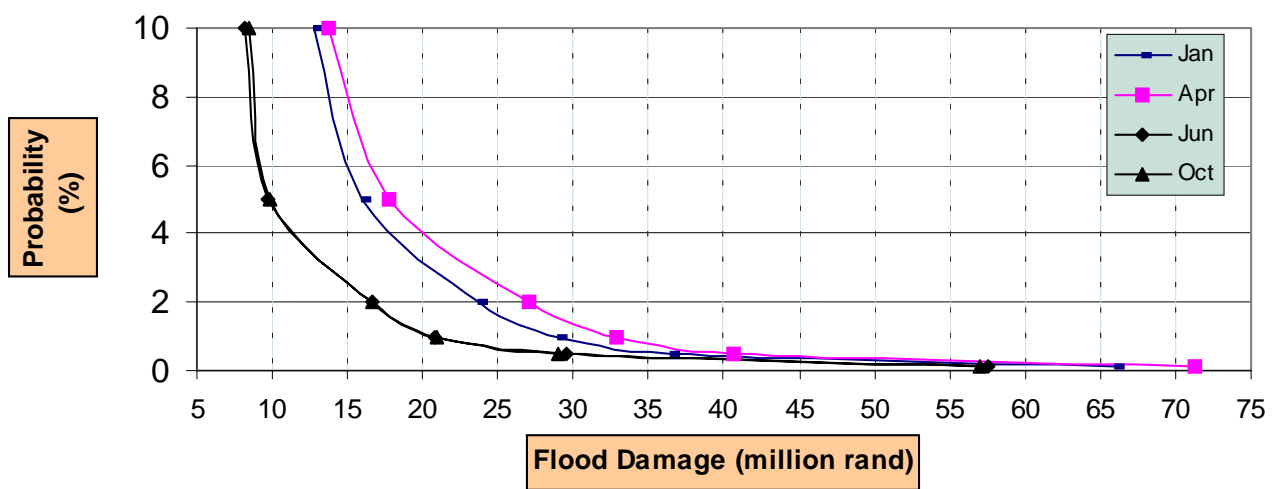

Figure 4

Flood damage probability distribution curves for Mfolozi flood-plain, 1995

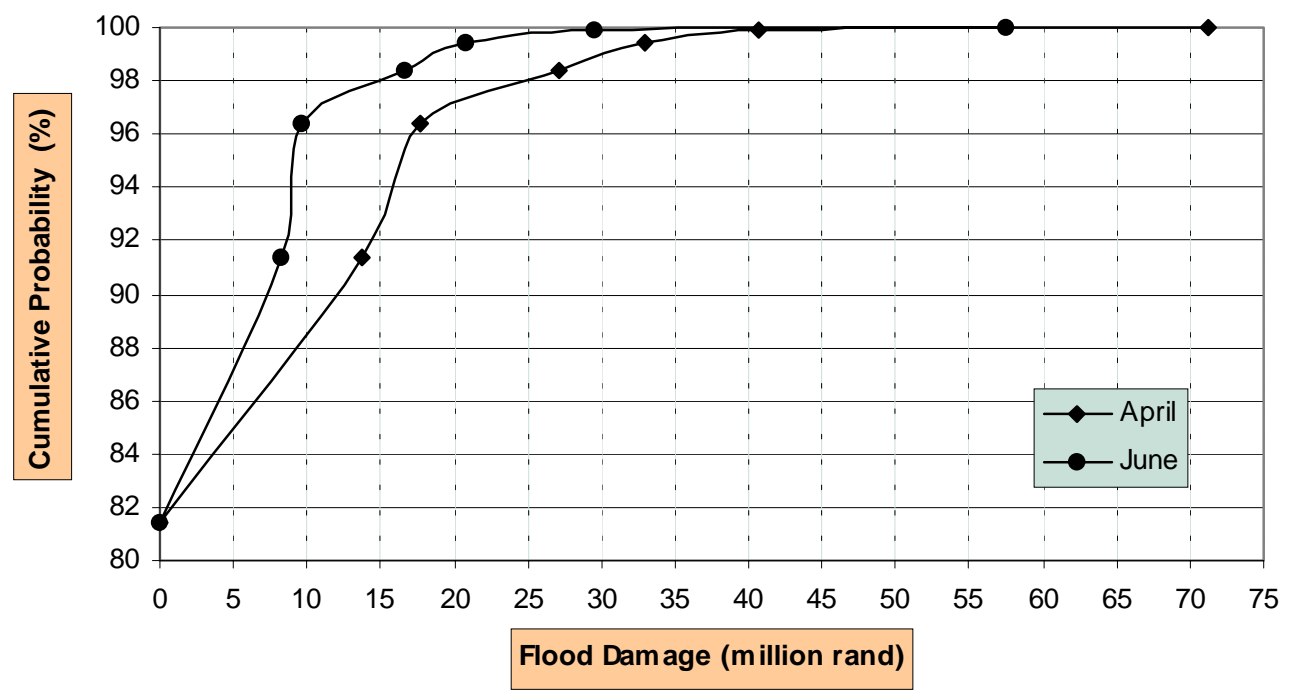

Figure 5

Less then cumulative flood damage probability distribution curve for the Mfolozi flood-plain, 1995

- Next, the assumption was made that the floods that were simulated, namely 10, 20, 50, 100, 200 and 1000 year floods, were distributed over 1000 years, and a one-in-ten-year flood would thus have occurred 100 times. The same principle applies to the other floods.

- When one looks at a 1000 year period, there will be years when no floods will occur and also some years when floods will occur, but will not be accompanied by any damage to property mainly because of flood mitigation measures. An assumption was also made that only 186 flood events will occur over a 1000 year period. For simulation purposes, provision were made only for the 10, 20, 50, 100, 200 and 1000 year floods.

- Because of existing flood control measures in the Mfoloziflood-plain, the smaller floods (smaller than the 10 year flood) cause no damage. The assumption implies that damage will occur after levees have been inundated, and not sooner as a result of erosion or collapse of levees.

According to these assumptions, damage will occur for the first time during the 10-year flood. As a result of this, there will indeed be years when no damage will occur on the Mfolozi flood-plain. This will be the case because, on the one hand, no floods will occur during certain years and, on the other hand, because of the fact that flood control measures will result in smaller floods (that occur more frequently), which cause no damage.

It can thus be assumed with an $81 \%$ certainty that no damage will occur on the Mfolozi flood-plain during a specific year. In other words, there will be an $81 \%$ chance that floods smaller than the 10-year floods will occur, but that, as a result of flood-control measures, these smaller floods will cause no damage. It is however important to note that there is still a $19 \%$ chance that damage will occur in any year.

Figure 5 can be divided into two parts: left of the double vertical line and to the right of the vertical line. With reference to the lefthand side, the conclusion can be drawn that the distribution is more stable compared to that of the right-hand side. Flood damage on the left-hand side of Fig. 5 can vary from no damage at all to damage to the amount of R17.71 m., while flood damage on the right-hand side of the vertical line can vary from R $17.71 \mathrm{~m}$. to more than $\mathrm{R} 70 \mathrm{~m}$. Because the distribution only changes by $24 \%$ to the left of the vertical line in comparison with a $76 \%$ change to the right, the distribution is more stable on the left-hand side.

If one compares a June to an April flood it is clear from Fig. 5 that floods that occur in June involve less risk than floods that occur in April. There is a 98\% chance that damage to the amount of $\mathrm{R} 17 \mathrm{~m}$. or less will result from a June flood, but there is still a $98 \%$ 
chance that flood damage to an amount of R32.89 m. or less will occur because of an April flood. Furthermore, depending on the time of the year in which floods occur, it can be assumed with a $96 \%$ certainty that damage will not exceed R17.71 m. in any year and with a $98 \%$ certainty that it will not exceed R $32.89 \mathrm{~m}$.. There is still a $1.5 \%$ chance that damage will exceed R32.89 m. This confirms the view that it can be stated with considerable certainty that flood damage will not exceed certain magnitude in any year (Van Zyl 1998).

\section{Conclusion and recommendations}

Because the traditional method of presenting flood damage in terms of the mean annual damage does not explicitly point out the risk of floods, communities do not have an indication of what the risk implication of various floods is. Therefore, flood-plain dwellers do not fully comprehend the nature, scope and potential effects of floods and cannot, because of a lack of information, fully comprehend the financial implication involved in those risks. To accommodate these problems cumulative probability distribution curves were constructed for the Mfolozi flood-plain in order to explain the risk of different floods lucidly to the community.

A clearer picture of the uncertainty of flood damage as well as of the implications of such damage can be created. This is an improvement on the traditional approach where only the mean annual flood damage is used. The total extent of the outcome (flood damage) is known and it is possible to indicate to the decisionmaker what the probability of a certain outcome will be. The inclusion of flood damage on a stochastic basis is most definitely an improvement on previous research on flood damage where data were only analysed, proceeding from a deterministic approach. With this approach flood-plain dwellers can comprehend better the nature, scope and potential effects of such risk.

It is recommended that this approach and procedures be incorporated in farm production practices. In this way it will be possible to construct CPDC for various crops in flood-plains to determine the potential flood risk to farmers engaged in different agricultural practices. In addition to encouraging production practices involving the least risk of damage, the nett risk to farm income which is derived from identified farm production practices in flood-plains can also be determined and explained better by means of CPDC.

\section{Summary}

In this paper the application of the flood damage simulation model (FLODSIM) to the Mfolozi flood-plain was discussed. Topographical data from 1:10 000 ortophotos (1979) were digitised and updated with the aid of 1996-aerial photography and digital data obtained from Bosch and Associates. A digital terrain model (DTM) was developed by the Division Geomatics of the Department of Water Affairs and Forestry. In the case of each sugar-cane field the height of the sugar-cane had to be compensated for in order to create a more accurate DTM.

Hydraulic data were supplied by the Division of Hydraulic Studies of the Department of Water Affairs and Forestry. The MIKE 11 hydraulic simulation model was used for this. In addition to damage to harvest and crops, damage also occurs to infrastructure such as roads, bridges, levees, tramways and the spillway. An enterprise budget for sugar-cane was drawn up and saved in the economic database.

Damage for the year was calculated and a distinct difference between summer and winter flood patterns came to the fore.
Damage is at its highest during April (MAD = R2.824 m.), in comparison with damage in June (MAD $=\mathrm{R} 1.562 \mathrm{~m}$.), with damage to infrastructure not included. In contrast to the Upington irrigation area, damage to harvests and crops is more or less of the same magnitude. The total mean annual flood damage for the Mfolozi flood-plain, with damage to infrastructure included, is $\mathrm{R} 3.27 \mathrm{~m}$. during the summer months. This is about R450 000 more per year than when damage to infrastructure is not included. Damage to various infrastructure categories was also calculated, and the most damage was done to levees (an average of R105 000 per annum). This is followed by damage to tramways, with the least damage to bridges.

Traditionally flood damage is presented in terms of the total mean annual damage, especially if flood control measures are compared from a benefit-cost point of view. One of the disadvantages of this method is that it does not point out the risks of floods explicitly. Subsequently, an adapted method was used to indicate the risks of flood damage for communities. It was found that it can be assumed with an $81 \%$ certainty that no damage will occur on the Mfolozi flood-plain in any given year. It is, however, possible that the absence of flood damage will be the result of existing flood control measures. It can also be assumed with a $98 \%$ certainty that flood damage in any year will not exceed the amount of R27 m., or that flood damage will not exceed R16.6 m. should floods occur during June. From this it can be concluded that the damage risk of an April flood is $39 \%$ higher than that of a June flood.

\section{Acknowledgements}

Financial support by the Water Research Commission to make the research possible is hereby acknowledged.

\section{References}

BERNING C, DU PLESSIS LA and VILJOEN MF (2000) Loss function for sugarcane: Depth and duration of inundation as determinants of extent of flood damage. Water SA 27 (1) 35-38.

BODIE Z and METON RC (1998) Finance. Upper Saddle River, NJ: Prentice Hall.

CAI R and MYBURGH NJ (1998) Lower Umfolozi Flats floodline numerical model. Report no W230/10/HH01. Pretoria, Department of Water Affairs and Forestry.

DU PLESSIS LA (2000) A new and unique approach for flood disaster management. Off. J. of the S. Afr. Inst. of Agric. Eng. 31 (1).

DU PLESSIS LA (1998) New flood damage simulation model for irrigation areas of South Africa: A GIS approach. Off. J. of the S. Afr. Inst. of Agric. Eng. 30 (1) 47-50.

DU PLESSIS LA, VILJOEN MF, WEEPENER HL and BERNING C (1998) Flood damage functions, models and a computer program for irrigation and urban areas in South Africa. Volume 1: Irrigation areas. WRC Report 889/1/98. Pretoria.

DU PLESSIS LA and VILJOEN MF (1997) The development of loss functions for the agricultural sector in the Lower Orange River. Water SA 23 ( 3) 209-216.

DU PLESSIS LA and VILJOEN MF (1996) Estimation of total direct flood damage in the Lower Orange River area with the aid of a flood simulation model: A GIS approach. Water SA 24 (3) 201-204.

DU PLESSIS LA and VILJOEN MF (1995) A flood damage simulation model for the reconstruction of a flood-plain. Agrekon 34 (4) 274-281.

HARDWOOD J, HEIFNER R, CBLE K, PERRY J and SOMWARU A (1999) Managing Risk in Farming: Concepts, Research and Analysis. Agricultural Economic Report, No. 774. Washington, US Dept. of Agric.

SCHUTTE CA (1997) Investigation into the Use of Digital Photogrammetry for Acquiring Digital Elevation Models. Department of Water Affairs and Forestry, Pretoria. Directorate of Survey Services. 
VAN ZYL JM (1998) Personal communication. Bloemfontein, Univ. of the Orange Free State, Dept. Math. Stat.

VILJOEN MF, SMITHDJG and SPIES PH(1981) Guidelines for Assessing Flood Damage in South Africa. Pretoria, Water Research Commission.
VILJOEN MF (1979) The Economics of Water Usage with Special Reference to the Determination of Flood Damage in Certain River Reaches of the Republic of South Africa. (In Afrikaans). Bloemfontein, Univ. of the Orange Free State, Inst. for Social and Econ. Res. 